\title{
Low-fat Brazilian cooked sausage-Paio - with added oat fiber and inulin as a fat substitute: effect on the technological properties and sensory acceptance
}

\author{
Camila Vespúcio Bis SOUZA ${ }^{1 *}$, Elisa Rafaela Bonadio BELLUCCI ${ }^{1}$, Jose Manuel LORENZO², \\ Andrea Carla da Silva BARRETTO ${ }^{1}$
}

\begin{abstract}
The aim of this study was to optimize the addition of oat fiber and inulin as fat substitutes in cooked Paio sausage using response surface methodology. The chemical composition, textural parameters, color properties, lipid oxidation, microbial analysis and sensory properties were assessed in twelve different treatments. The addition of dietary fiber led to a significant $(P<0.05)$ increase in moisture content and also a decrease in fat content of between $60.78 \%$ and $63.16 \%$. Color parameters were significantly affected by the addition of inulin and oat fiber, as lightness decreases with the addition of oat fiber. Similar happened with redness, the lowest results were for the treatment with higher dietary fiber content added. Regarding lipid oxidation, the inclusion of fiber did not influence the TBARS values among treatments and throughout the storage time. Sausages manufactured with inulin and oat fiber present similar scores for color, taste and overall acceptability, while lower texture values were found in sausages manufactured with oat fiber. The addition of up to $6 \%$ of inulin with up to $0.85 \%$ oat fiber in a low fat cooked Paio sausage did not compromise technological parameters and sensory acceptably.
\end{abstract}

Keywords: dietary fibre; meat products; consumer acceptability studies; texture profile analysis; reformulation.

Practical Application: Optimization of the application of oat fiber and inulin as fat substitute in Brazilian cooked sausage-Paio.

\section{Introduction}

The food industry has shown great interest in reformulating traditional products, due to the growing concern of the population in maintaining a healthy and balanced diet. Traditional meat products have a high fat content, and from the nutritional point of view, a reduction in fat content aims to help consumers reduce the intake of large amounts of saturated fatty acids and cholesterol from animal fat. This excessive consumption is associated with the possible development of cardiovascular disease and other types of chronic diseases (Del Nobile et al., 2009; Trevisan et al., 2016). In Brazil, according to data from the Health Ministry, obesity has increased by $60 \%$ in the last ten years, contributing to high rates of chronic diseases like diabetes and hypertension (Brazil, 2017). There is a growing concern about producing processed meat products with a higher nutritional balance.

Such reformulations can modify important properties such as parameters of texture, color, yield, microbiological stability and sensorial characteristics, especially meat products (Domínguez et al., 2016; Pintado et al., 2018). In this regard, the use of dietary fiber in meat products as fat substitute could minimize the technological and sensory negative effects.

These fibers have technological properties which improve the final texture of the product, increase the water-binding, maintain a good yield and reduce the cost of formulating a low-fat meat product (Trevisan et al., 2016; Kehlet et al., 2017). Oat fiber and wheat fiber increase the retention capacity of water and fat and they also can improve the yield reducing the water loss during cooking (Elleuch et al., 2011). Thus, their incorporation in widely consumed meat products can encourage healthier consumption habits, helping in the reduction of problems related to public health.

Brazilian cooked sausage - Paio - is a cooked meat product which can be made with the meat from three different animals (beef, pork and poultry- limited to $20 \%$ of mechanically deboned poultry meat - MDPM) and the total fat content is limited to $35 \%$ (Brasil, 2000). Paio is a very popular meat product in Brazil, especially as it is a main ingredient in one of the most traditional dishes in Brazilian culture, the "feijoada" (black bean and pork stew). So, this scientific study will help with the reformulation of cooked Paio sausage proposing a new way of producing a healthier meat product that can be included in the Brazilian diet. The aim of this study was to optimize the addition of oat fiber and inulin in cooked Paio sausage, using response surface methodology, to reduce the saturated fat content and to evaluate this effect on the technological properties and acceptability.

\section{Material and methods}

\subsection{Low-fat Paio processing}

Fresh beef (moisture 72.95\%; fat 5.35\%) and lean pork (moisture 71.06\%; fat 9.53\%) were provided by an industrial supplier (Frigorífico Olhos D’água, Ipuã, Brazil), while Frigorífico

${ }^{1}$ Departamento de Engenharia e Tecnológica de Alimentos, Instituto de Biociência, Letras e Ciências Exatas, Universidade Estadual Paulista - UNESP, São José do Rio Preto, SP, Brasil 
Céu Azul (Guapiaçu, Brasil) provided mechanically deboned poultry meat (MDPM). The dietary fibers used were: Orafti ${ }^{\circledR}$ inulin (moisture 3\%; total of soluble dietary fiber 90\%) from Clariant (São Paulo, Brazil) and oat fiber (moisture 7\%; total of insoluble dietary fiber 96\%) from JRS Rettenmeyer ${ }^{\circledR}$ (São Paulo, Brazil). All processing steps were performed at the Laboratory of Meat and Meat Derivatives of the Department of Food Technology and Engineering (IBILCE / UNESP). All the processing was done following the good manufacturing practices.

All ingredients were weighed and mixed according to the corresponding formulation (Table 1). The amount of oat fiber and inulin added in the formulation followed the factorial design (Table 2). A control formulation (C1) was produced to compare the total caloric content of cooked low-fat Paio sausage and to quantify the reduction in fat content in the final product. These formulations were stuffed into previously rehydrated natural casings and tied into $15 \mathrm{~cm}$ sausages. Those sausages were cooked at a controlled temperature $\left(60^{\circ} \mathrm{C} / 20\right.$ minutes; then $80^{\circ} \mathrm{C}$ until the internal temperature $72^{\circ} \mathrm{C}$ ). The samples were cooled and

Table 1. Formulation of control and low-fat Paio.

\begin{tabular}{lcc}
\hline \multicolumn{1}{c}{ INGREDIENTS } & C1 (\%) & RUN (\%) \\
\hline Pork lean & 10 & 30 \\
Fresh beef & 20 & 20 \\
MDPM & 20 & 20 \\
Pork back fat & 20 & - \\
Cold water & 22.985 & $12.745-22.985$ \\
Texturized soy protein & 4.5 & 4.5 \\
Flavoring & 0.3 & 0.3 \\
Salt & 2 & 2 \\
Monosodium glutamate & 0.2 & 0.2 \\
Sodium acid pyrophosphate & 0.4 & 0.4 \\
Natural smoke flavor & 0.05 & 0.05 \\
Sodium erythorbate & 0.5 & 0.5 \\
Natural dye (cochineal carmine) & 0.05 & 0.05 \\
Sodium nitrite & 0.015 & 0.015 \\
Oat fiber & - & 1 \\
Inulin & - & 1 \\
\hline${ }^{1}$ Acording to the factorial design & &
\end{tabular}

Table 2. Matrix of experimental design.

\begin{tabular}{ccccccc}
\hline \multirow{2}{*}{ Run } & \multirow{2}{*}{ Randomization } & \multicolumn{2}{c}{ Coded variables } & & \multicolumn{2}{c}{ Real variables } \\
\cline { 3 - 4 } \cline { 6 - 7 } & & $\mathrm{X}_{1}$ & $\mathrm{X}_{2}$ & & $\mathrm{X}_{1}(\%)$ & $\mathrm{X}_{2}(\%)$ \\
\hline 1 & 4 & -1 & -1 & & 0.87 & 0.87 \\
2 & 8 & 1 & -1 & & 5.12 & 0.87 \\
3 & 5 & -1 & 1 & & 0.87 & 5.12 \\
4 & 10 & 1 & 1 & & 5.12 & 5.12 \\
5 & 6 & 0 & 0 & & 3 & 3 \\
6 & 11 & 0 & 0 & & 3 & 3 \\
7 & 2 & 0 & 0 & & 3 & 3 \\
8 & 12 & 0 & 0 & & 3 & 3 \\
9 & 1 & -1.41 & 0 & & 0 & 3 \\
10 & 7 & 1.41 & 0 & & 6 & 3 \\
11 & 3 & 0 & -1.41 & & 3 & 0 \\
12 & 9 & 0 & 1.41 & & 3 & 6 \\
\hline
\end{tabular}

vacuum-packed in transparent plastic bags, with a final weight of $500 \mathrm{~g}$. The samples were stored for 30 days at a refrigerated temperature $\left(4^{\circ} \mathrm{C}\right)$. Each batch produced was $4.5 \mathrm{~kg}$ and each Paio sample weighed approximately $200 \mathrm{~g}$.

\subsection{Experimental design}

A central composite rotational design (CCRD) was used to investigate the effect of two independent variables (oat fiber and inulin) on the physicochemical and sensory properties of low-fat cooked Paio sausage. The experimental design ( $2^{2}$ factorial design) with five coded and real levels are presented in Table 2 . The factorial design was conducted with four factorial points $(+1,-1)$, four axial points $(+\alpha,-\alpha)$ and four repetition of central points $(0)$. The response variables were yield, hardness, cohesiveness, springiness, chewiness, lightness, redness, yellowness, whiteness and the sensory attributes.

\subsection{Proximate composition and total caloric content}

The total moisture and protein content were determined according to the method proposed by the Association of Official Analytical Chemists (Association of Official Analytical Chemists, 2007), and the fat content was determined following the method by Bligh \& Dyer (1959). Available carbohydrates were calculated by difference. This analysis was performed in triplicate. The estimates of total caloric content were calculated according to Jiménez-Colmenero et al. (2010) and some modifications. For $100 \mathrm{~g}$ of the sample the values used were corresponding to fat $\left(9 \mathrm{kcal} . \mathrm{g}^{-1}\right)$, protein $\left(4.02 \mathrm{kcal.g}{ }^{-1}\right)$, carbohydrates $\left(3.87 \mathrm{kcal}_{\mathrm{g}} \mathrm{g}^{-1}\right)$, oat fiber $\left(0.06 \mathrm{kcal} . \mathrm{g}^{-1}\right)$ and inulin $\left(1.50 \mathrm{kcal}^{\mathrm{g}} \mathrm{g}^{-1}\right)$ for each formulation. The values related to dietary fibers were obtained from the manufacturers. The fat reduction (FR\%) was determined according to equation 1, using the total fat content of the control formulation.

$\mathrm{FR} \%=100-\left(\frac{\text { Fat content } \times 100}{19.30}\right)$

\subsection{Yield and Texture Profile Analysis (TPA)}

Yield was calculated from the difference between raw weight and cooked weight of low-fat Paio (Berry, 1992). This analysis was performed in triplicate.

The texture profile analysis for the low-fat Paio was performed using the TA-XT/Plus/50 texture analyzer (StableMicroSystems, Godalming, England) and the proprietary software Texture Expert. The parameters evaluated in sextuplicate were hardness, springiness, cohesiveness and chewiness. The samples, at room temperature $\left(25^{\circ} \mathrm{C}\right.$ ) (height $2 \mathrm{~cm}$ and diameter $2.5 \mathrm{~cm}$ ) were submitted to two cycles of compression (50\%) by a cylindrical probe of $2.5 \mathrm{~cm}$ diameter and a pre-test speed of $2.0 \mathrm{~mm} . \mathrm{s}^{-1}$ a test speed of $1.0 \mathrm{~mm} \cdot \mathrm{s}^{-1} \mathrm{~s}$ and a post-test speed of $10 \mathrm{~mm} \cdot \mathrm{s}^{-1}(\mathrm{n}=10)$.

\subsection{Instrumental color}

The color evaluation was performed using a ColorFlex $45 / 0$ spectrophotometer (Hunterlab, Reston, VA, USA), with an observation angle of $10^{\circ}$, illuminant D65 and Universal software 
version 4.10. The CIELAB color specification system was used (Tapp et al., 2011) and the color coordinates determined were lightness ( $\mathrm{L}^{*}$ value), redness ( $\mathrm{a}^{*}$ value) and yellowness $\left(\mathrm{b}^{*}\right.$ value). Whiteness value was calculated from $L^{*}, a^{\star}$ and $b^{*}$ values using the calculation described by de Oliveira Faria et al. (2015) as in equation $2(\mathrm{n}=10)$. The color determination was performed using the internal part of the Paio.

$$
\text { Whiteness }=100-\left[\left(100-\mathrm{L}^{*}\right)^{2}+\mathrm{a} *^{2}+\mathrm{b}^{* 2}\right]^{1 / 2}
$$

\subsection{TBARS value}

Lipid oxidation was assessed in all treatments of low-fat Paio cooked sausage with added dietary fibers following the recommendations described by Vyncke (1970). The TBARS value was measured from a standard curve of malonaldehyde (MA) and expressed as mg MA kg of sample ${ }^{-1}$. The analyses were performed in triplicate.

\subsection{Microbiological analysis}

The microbiological analysis was performed with control and treatment according to the limits established by the Brazilian Legislation (Brasil, 2001) to verify the hygienic quality of the sample. The sample of all the treatments were ground in a sterile container, weighed $(10 \mathrm{~g})$ and diluted in $90 \mathrm{~mL}$ of sterile peptone water (HIMEDIA, Mumbai, India) for investigation of thermotolerant coliforms, coagulase-positive Staphylococci and sulfite-reducing clostridia. The presence of Salmonella sp. in $25 \mathrm{~g}$ of sample was determined using the dilution in $225 \mathrm{~mL}$ of lactose broth (HIMEDIA, Mumbai, India). Thermotolerant coliforms were identified using the multiple-tube fermentation test and expressed as most probable number (MPN) g sample ${ }^{-1}$. Coagulase-positive Staphylococci were identified by inoculating samples in Baird Parker Agar (HIMEDIA, Mumbai, India) enriched egg yolk and potassium tellurite $1 \%$. Sulfite-reducing clostridia were counted by inoculating samples in SPS Agar (HIMEDIA, Mumbai, India) in anaerobic jars. All these measurements were done in duplicate and the results were expressed in log CFU $g$ of sample s. $^{-1}$.

\subsection{Sensory analysis}

The acceptability test was performed at the Sensory Analysis Laboratory of the Department of Food Technology and Engineering (UNESP, São José do Rio Preto, SP, Brazil). The study was approved by the Ethics in Research Committee of the São Paulo State University (UNESP) (Protocol no 948.501.) Seventy-one non-trained potential consumers were recruited among students and staff of the São Paulo State University (UNESP). Each sample was coded with a three-digit number and the presentation was randomized in a sequential monadic way, following a balanced complete block design divided into three sessions (four samples each session) as proposed by Meilgaard et al. (2007). The tests were performed in individual booths under white light and at a temperature of $22^{\circ} \mathrm{C}$. All panelists evaluated one sample of all treatments in a randomized order. Unsalted crackers and water at room temperature were provided to clean the palate between each sample. A nine-point hedonic scale ( $1=$ extremely disliked and $9=$ extremely liked) was used and the four attributes evaluated were color, taste, texture and overall acceptance.

\subsection{Statistical analysis}

The variable responses were correlated with the independent variables by analyzing their effects $(P \leq 0.05)$ using response surface methodology and the regression coefficients were expressed in the mathematical model given in equation 3 .

$$
\mathrm{Y}=\mathrm{b}_{0}+\mathrm{b}_{1} \mathrm{X}_{1}+\mathrm{b}_{2} \mathrm{X}_{2}+\mathrm{b}_{11} \mathrm{X}_{1}^{2}+\mathrm{b}_{22} \mathrm{X}_{2}^{2}+\mathrm{b}_{12} \mathrm{X}_{1} \mathrm{X}_{2}
$$

Where:

$\mathrm{Y}=$ Response function

$\mathrm{b}_{0}=$ Regression Coefficients

$\mathrm{X}_{1}$ e $\mathrm{X}_{2}$ = Values of independents variables.

The statistical software used was Statistica 7.0 (StatSoft, Tulsa, USA). The minimum regression coefficient, determined by ANOVA, was $\mathrm{R}^{2}=60$, to ensure the prediction validity of the mathematical model. In addition, principal component analysis (PCA) was performed between the technological parameters and sensory attributes, using Statistica 7.0 (StatSoft, Tulsa, USA). For PCA analysis, the response variables were fixed in columns and the low-fat Paio treatments in rows and the data were standardized before analysis. A correlation matrix without factor rotation was used.

\section{Results and discussion}

\subsection{Proximate composition and total calories content}

The moisture content of the final product was influenced by the percentage of water added in the formulation. The dietary fibers added to the Paio formulation showed an effect on the increase of water binding capacity and led to a significant increase in moisture content $(P<0.05)$ (Table 3$)$. Similar results were found by Alves et al. (2016) when they replaced pork back fat with pork skin and green banana flour gel in a bologna type sausage and in which the replacement of $20 \%$ to $100 \%$ of the fat significantly increased the moisture of this product compared to the control batch. By replacing $10 \%$ chicken fat with $2 \%$ pea fiber with $8 \%$ water in nuggets of chicken, Polizer et al. (2015) observed an increase in the value of moisture compered to control treatment.

The cooked Paio sausage with added dietary fibers showed a fat reduction of between $60.78 \%$ and $63.16 \%$ compared with the control treatment. The average value for the caloric content of cooked Paio sausage was $146.63 \mathrm{kcal}_{\text {. }}{ }^{-1}$ (Table 3 ). The control sample showed a caloric content of $215 \mathrm{kcal} . \mathrm{g}^{-1}$. This reduction can be attributed to the lower fat content in low-fat products and the addition of dietary fibers, that have low caloric value. The partial replacement of fat by dietary fiber in Brazilian cooked sausage Paio achieved a reduction in the calorific value $32 \%$ compared to control. This decreasing of calories can assist consumers with healthier meat product choices, those which have a reduced saturated fat content. All treatments of this study can be considered "Reduce calorific value" options because a reduction over to $25 \%$ of caloric value compared to control as established in Resolution RDC No. 54/ 2012 for use of Complementary Nutrition Information (INC) in Food (Brasil, 2012). 
Table 3. Characterization of low-fat Brazilian cooked sausage Paio and control.

\begin{tabular}{cccccccc}
\hline Run $^{1}$ & $\begin{array}{c}\text { Moisture } \\
\left(\mathrm{g} \mathrm{kg}^{-1}\right)\end{array}$ & $\begin{array}{c}\text { Ash } \\
\left(\mathrm{g} \mathrm{kg}^{-1}\right)\end{array}$ & $\begin{array}{c}\text { Fat } \\
\left(\mathrm{g} \mathrm{kg}^{-1}\right)\end{array}$ & $\begin{array}{c}\text { Fat reduction } \\
(\%)\end{array}$ & $\begin{array}{c}\text { Protein } \\
\left(\mathrm{g} \mathrm{kg}^{-1}\right)\end{array}$ & $\begin{array}{c}\text { Carbohydrates } \\
\text { Cotal calories } \\
\left(\mathrm{Kcal} \mathrm{g}^{-1}\right)\end{array}$ \\
\hline Control & $62.50^{\mathrm{e}}$ & $3.00^{\mathrm{a}}$ & $19.30^{\mathrm{a}}$ & - & $18.20^{\mathrm{a}}$ & 1.00 & 214.73 \\
$\mathbf{1}$ & $68.42^{\mathrm{a}}$ & $3.06^{\mathrm{a}}$ & $7.32^{\mathrm{b}}$ & 62.07 & $18.39^{\mathrm{a}}$ & 2.81 & 145.09 \\
$\mathbf{2}$ & $65.11^{\mathrm{cd}}$ & $2.96^{\mathrm{a}}$ & $7.17^{\mathrm{b}}$ & 62.85 & $17.76^{\mathrm{a}}$ & 7.00 & 141.41 \\
$\mathbf{3}$ & $65.05^{\mathrm{cd}}$ & $3.00^{\mathrm{a}}$ & $7.15^{\mathrm{b}}$ & 62.95 & $17.73^{\mathrm{a}}$ & 7.07 & 147.33 \\
$\mathbf{4}$ & $60.41^{\mathrm{f}}$ & $2.81^{\mathrm{a}}$ & $7.30^{\mathrm{b}}$ & 62.18 & $19.18^{\mathrm{a}}$ & 10.30 & 153.93 \\
$\mathbf{5}$ & $65.95^{\mathrm{c}}$ & $2.82^{\mathrm{a}}$ & $7.29^{\mathrm{b}}$ & 62.23 & $17.58^{\mathrm{a}}$ & 6.26 & 144.25 \\
$\mathbf{6}$ & $65.54^{\mathrm{c}}$ & $3.30^{\mathrm{a}}$ & $7.28^{\mathrm{b}}$ & 62.28 & $17.49^{\mathrm{a}}$ & 6.40 & 143.91 \\
$\mathbf{7}$ & $65.38^{\mathrm{c}}$ & $3.10^{\mathrm{a}}$ & $7.21^{\mathrm{b}}$ & 62.64 & $17.37^{\mathrm{a}}$ & 6.95 & 143.23 \\
$\mathbf{8}$ & $65.85^{\mathrm{c}}$ & $2.98^{\mathrm{a}}$ & $7.36^{\mathrm{b}}$ & 61.87 & $17.22^{\mathrm{a}}$ & 6.59 & 143.69 \\
$\mathbf{9}$ & $66.11^{\mathrm{bc}}$ & $2.95^{\mathrm{a}}$ & $7.44^{\mathrm{b}}$ & 61.45 & $18.81^{\mathrm{a}}$ & 4.70 & 152.00 \\
$\mathbf{1 0}$ & $63.51^{\mathrm{de}}$ & $3.10^{\mathrm{a}}$ & $7.11^{\mathrm{b}}$ & 63.16 & $18.19^{\mathrm{a}}$ & 8.12 & 144.82 \\
$\mathbf{1 1}$ & $67.66^{\mathrm{ab}}$ & $2.99^{\mathrm{a}}$ & $7.57^{\mathrm{b}}$ & 60.78 & $18.39^{\mathrm{a}}$ & 3.39 & 10.57 \\
$\mathbf{1 2}$ & $60.63^{\mathrm{f}}$ & $3.02^{\mathrm{a}}$ & $7.35^{\mathrm{b}}$ & 61.92 & $18.43^{\mathrm{a}}$ & 146.07 \\
SEM & 0.322 & 0.123 & 0.229 & - & 0.458 & - \\
p-value & $<0.05$ & $\mathrm{~ns}$ & $<0.05$ & - & $\mathrm{ns}^{2}$ & - \\
\hline
\end{tabular}

${ }^{1}$ Control: no addition of dietary fiber and with $20 \%$ of fat; 1 : low-fat with $0.87 \%$ oat fiber plus $0.87 \%$ inulin; 2 : low-fat with $5.12 \%$ oat fiber plus $0.87 \%$ inulin; 3 : low-fat with $0.87 \%$ oat fiber plus 5.12\% inulin; 4: low-fat with 5.12\% oat fiber plus 5.12\% inulin; 5: low-fat with 3\% oat fiber plus 3\% inulin; 6: low-fat with $3 \%$ oat fiber plus 3\% inulin; 7 : low-fat with $3 \%$ oat fiber plus 3\% inulin; 8: low-fat with 3\% oat fiber plus 3\% inulin; 9: low-fat with 3\% inulin; 10: low-fat with $6 \%$ oat fiber plus $3 \%$ inulin; 11: low-fat with 3\% oat fiber; 12: low-fat with $3 \%$ oat fiber plus $6 \%$ of inulin. SEM $=$ standard error of the mean. ns: no Significant $(P>0.05) .{ }^{2}$ Determined by difference. ${ }^{\text {abcdef }}$ Different lowercase letters in the same column indicate significant difference $(P<0.05)$ by Tukey's test.

Another trial conducted to develop a beef burger with partial replacement of fat and meat by hydrated wheat fiber also observed a significant reduction in the calorific value of the low-fa product by purchasing with control. The authors noted a reduction of $36.2 \%$ in the sample with addition of $6.25 \%$ of hydrated wheat fiber comparing to control (Carvalho et al., 2019).

\section{Yield and texture profile analysis}

The dietary fibers affected yields, which increased significantly from $80.57 \%$ to $91.94 \%$. Higher concentrations of oat fiber corresponded to higher yields of low-fat Paio, probably due that oat fiber is insoluble fiber. Oat fiber is known for its high-water retention capacity which besides influencing the yield can have an effect on the texture parameters (Steenblock et al., 2001; Liu et al., 2015). Similar results were reported by Alves et al. (2016) that used green banana flour as a fat replacer in bologna type sausage. The yield was higher in the low-fat formulation with $20 \%$ less fat when compared to the control batch. According to Henning et al. (2016) the partial replacement of pork back fat with pineapple dietary fibers did not show significant differences between beef sausage. The incorporation of $6 \%$ of two different insoluble fibers (oat and wheat fiber) improved the yield of cooked low-fat beef burger (Bis-Souza et al., 2018).

The ability to increase the yield is connected to the water-binding capacity of the dietary fiber. Each fiber has a unique ability for hydration and its capacity to retain the water in the system. This difference is because of their chemical structure, $\mathrm{pH}$, ionic strength and particle size (Han \& Bertram, 2017). The higher water-binding capacity of the fat replacer corresponded to the higher yield of the cooked meat product. The model (Table 4) was built and the response surface (Figure 1a) was produced.
The addition of $2 \%$ of inulin as fat substitute in meat emulsion did not show significant differences between the modified sausages and the control group, although other fat replacers tested in the same proportion (CMC, cellulose, Chitosan and pectin) significantly increased the yield (Han \& Bertram, 2017). On the contrary, Afshari et al. (2015) reported that the addition of inulin $(8 \% \mathrm{w} / \mathrm{w})$ in low-fat beef burger decreased yields. The oat fiber increased the hardness, but the inulin did not affect this textural parameter in low-fat Paio. The model (Table 4) was built and the response surface (Figure 1b) was produced. The oat fiber in high concentrations provides a harder product. This finding is in agreement with data reported by Schmiele et al. (2015) who observed that the inclusion of amorphous cellulose fiber (insoluble fiber) in a cooked meat product increased the hardness. A similar result was also noticed by Petersson et al. (2014) - that when oat bran was used as a fat substitute in cooked sausage, firmness increased when compared to the control sausages.

In another study by Han \& Bertram (2017), the addition of inulin as a fat replacer (2\%) in meat emulsion did not show significant differences compared to the control group. However, the addition of $2 \%$ of cellulose and chitosan increased the hardness compared to the control treatment, and the use of CMC and pectin decreased the hardness. On the other hand, Keenan et al. (2014) reported that the addition of inulin to breakfast sausage to replace pork back fat increased the hardness. According to Afshari et al. (2015), the addition of inulin (8\%) in low-fat beef burger contributed to increased hardness. However, the combination of $\beta$-glucan/inulin had a different effect on the texture of low-fat beef burger, being lower than the control.

Oat fiber and inulin affected the cohesiveness of cooked Paio sausage. The model (Table 4) was built and the response surface (Figure 1c) was produced. The results for cohesiveness increased from 0.41 to 0.54 when oat fiber was added in the 
(a)

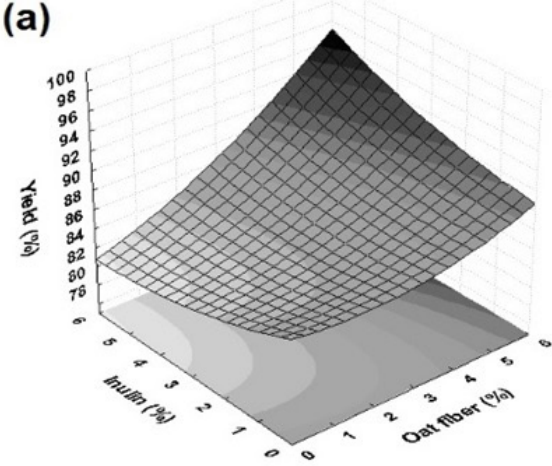

(d)

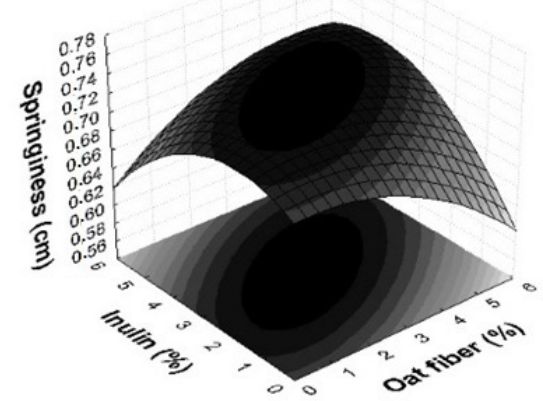

(b)

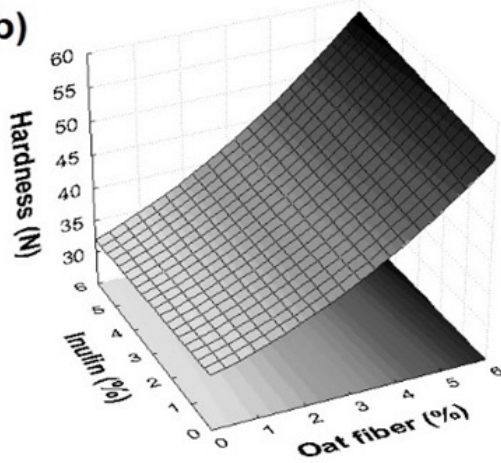

(e)

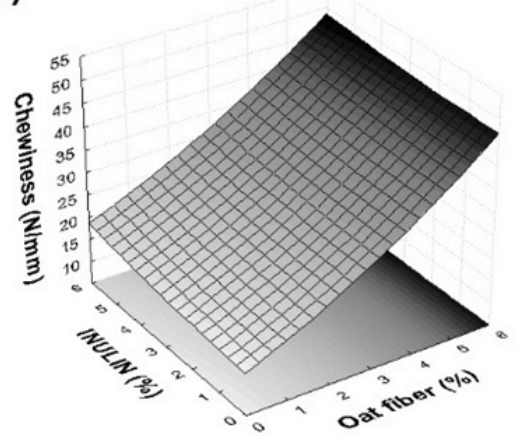

(c)

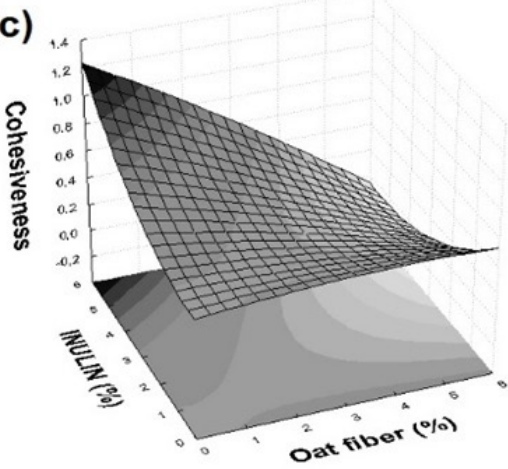

(f)

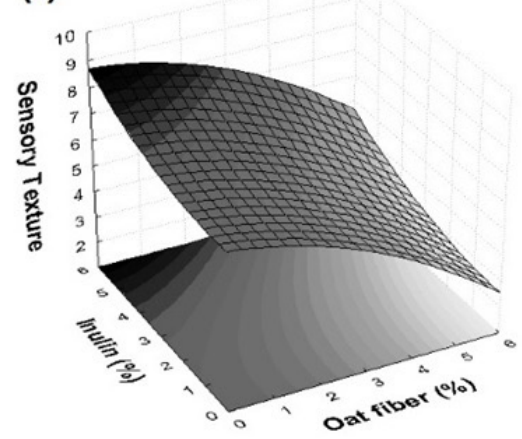

Figure 1. Response surface of: yield (a); hardness (b); cohesiveness (c); springiness (d); chewiness (e); sensory texture (f) showing the effects of oat fiber and inulin as fat substitute of the cooked Paio sausage.

Table 4. Model equations, p-value, and lack of fit for the significantly effects of dietary fibers as fat substitute in low-fat Paio.

\begin{tabular}{|c|c|c|c|c|}
\hline Dependent variable & Model & $\mathrm{R}^{2}$ & p-value & Lack of Fit \\
\hline Yield $(\%)$ & $\mathrm{y}=84.7961+3.0723 \cdot x_{1}+0.85803 \cdot x^{2}{ }_{1}+1.44125 \cdot x_{1} \cdot x_{2}$ & 0.880 & $<0.05$ & 0.060 \\
\hline $\operatorname{Hardness}(\mathrm{N})$ & $\mathrm{y}=41.633+8.496 . \mathrm{x}_{1}$ & 0.863 & $<0.05$ & 0.018 \\
\hline Cohesiveness & $\mathrm{y}=0.4726+0.0368 \cdot \mathrm{x}_{1}-0.0375 \cdot \mathrm{x}_{1} \cdot \mathrm{x}_{2}$ & 0.861 & $<0.05$ & 0.454 \\
\hline Springiness $(\mathrm{cm})$ & $y=0.7399-0.0263 . x_{2}^{2}$ & 0.679 & $<0.05$ & 0.187 \\
\hline Chewiness $(\mathrm{N} / \mathrm{cm})$ & $\mathrm{y}=14.397+3.812 . \mathrm{x}_{1}$ & 0.895 & $<0.05$ & 0.061 \\
\hline Sensory texture & $\mathrm{y}=7.007-0.1967 . \mathrm{x}_{1}$ & 0.623 & $<0.05$ & 0.479 \\
\hline
\end{tabular}

$\mathrm{X}_{1-}$ Oat fiber; $\mathrm{X}_{2 .}$ Inulin; $\mathrm{R}^{2}$ - Determination coefficient.

highest concentration. This outcome is different from that reported by Huber et al. (2016), who obtained lower cohesiveness in low-fat chicken burger when the concentration of vegetable fibers (bamboo, pea and wheat) was over $2 \%$. The inulin showed a quadratic effect in the springiness of low-fat Paio. The model (Table 4) was built and the response surface (Figure 1d) was produced. The lowest concentrations of inulin presented the highest springiness values. Oat fiber affected the chewiness of low-fat Paio, which increased significantly from $9.48 \mathrm{~N} . \mathrm{cm}^{-1}$ to $20.59 \mathrm{~N} . \mathrm{cm}^{-1}$. The model (Table 4) was built and the response surface (Figure 1e) was produced. This outcome is in agreement with data reported by Alves et al. (2016), who observed a decrease in chewiness when green banana flour was used as a fat replacer in bologna type sausage.

\section{Instrumental color}

The obtained results show significant differences on instrumental color (Table 5) parameters among treatments, indicating that the color of low-fat Paio was not affected by the addition of inulin and oat fiber.

According to Alves et al. (2016), the replacement of pork back fat (up to $60 \%$ of reduction) for pork skin and green banana flour gel in bologna type sausage did not affect the color parameters (lightness, redness, yellowness and whiteness). However, the substitution of $80 \%$ or $100 \%$ of the fat showed a decrease in lightness and redness, compared to the control treatment. The incorporation of only one type of dietary fiber in the cooked Paio sausage (T9- 3\% of inulin; T11- 3\% of oat fiber) 
Table 5. Experimental results of instrumental color and lipid oxidation stability.

\begin{tabular}{|c|c|c|c|c|c|c|}
\hline $\operatorname{Run}^{1}$ & Lightness & Redness & Yellowness & Whiteness & L.O 0 day & L.O 30 days \\
\hline 1 & $54.2^{\mathrm{bc}}$ & $14.7^{\mathrm{ab}}$ & $14.1^{\mathrm{b}}$ & $49.9^{\mathrm{bc}}$ & $0.156^{\mathrm{a}}$ & $0.138^{\mathrm{a}}$ \\
\hline 2 & $54.1^{\mathrm{bc}}$ & $14.4^{\mathrm{bc}}$ & $14.5^{\mathrm{a}}$ & $49.8^{\mathrm{bc}}$ & $0.139^{\mathrm{a}}$ & $0.135^{\mathrm{a}}$ \\
\hline 3 & $56.4^{\mathrm{a}}$ & $15.1^{\mathrm{a}}$ & $13.5^{\mathrm{de}}$ & $51.9^{\mathrm{a}}$ & $0.174^{\mathrm{a}}$ & $0.106^{\mathrm{a}}$ \\
\hline 4 & $52.9^{\mathrm{cd}}$ & $14.4^{\mathrm{bc}}$ & $14.0^{\mathrm{bc}}$ & $48.8^{\mathrm{bcd}}$ & $0.234^{\mathrm{a}}$ & $0.114^{\mathrm{a}}$ \\
\hline 5 & $54.2^{\mathrm{bc}}$ & $15.0^{\mathrm{a}}$ & $13.3^{\mathrm{ef}}$ & $50.0^{\mathrm{b}}$ & $0.131^{\mathrm{a}}$ & $0.147^{\mathrm{a}}$ \\
\hline 6 & $52.9^{c}$ & $14.4^{\mathrm{bc}}$ & $13.7^{\mathrm{cde}}$ & $48.9^{\mathrm{bc}}$ & $0.153^{\mathrm{a}}$ & $0.111^{\mathrm{a}}$ \\
\hline 7 & $52.8^{\mathrm{cd}}$ & $14.1^{\mathrm{cd}}$ & $14.2^{\mathrm{ab}}$ & $48.7^{\mathrm{cd}}$ & $0.167^{\mathrm{a}}$ & $0.133^{\mathrm{a}}$ \\
\hline 8 & $54.5^{\mathrm{b}}$ & $15.2^{\mathrm{a}}$ & $14.2^{\mathrm{ab}}$ & $49.9^{\mathrm{bc}}$ & $0.139^{a}$ & $0.104^{\mathrm{a}}$ \\
\hline 9 & $48.7^{\mathrm{e}}$ & $14.2^{\mathrm{cd}}$ & $13.1^{\mathrm{f}}$ & $45.2^{\mathrm{e}}$ & $0.187^{a}$ & $0.121^{\mathrm{a}}$ \\
\hline 10 & $52.9^{c}$ & $13.9^{\mathrm{d}}$ & $14.3^{\mathrm{ab}}$ & $48.9^{\mathrm{bc}}$ & $0.131^{\mathrm{a}}$ & $0.145^{\mathrm{a}}$ \\
\hline 11 & $49.2^{\mathrm{e}}$ & $14.2^{\mathrm{cd}}$ & $13.4^{\mathrm{def}}$ & $45.6^{\mathrm{e}}$ & $0.182^{\mathrm{a}}$ & $0.123^{\mathrm{a}}$ \\
\hline 12 & $51.4^{\mathrm{d}}$ & $14.2^{\mathrm{cd}}$ & $13.7^{\mathrm{cd}}$ & $47.6^{\mathrm{d}}$ & $0.144^{\mathrm{a}}$ & $0.137^{\mathrm{a}}$ \\
\hline SEM & 0.31 & 0.09 & 0.07 & 0.26 & 0.14 & 0.11 \\
\hline p-value & $>0.05$ & $>0.05$ & $>0.05$ & $>0.05$ & ns & ns \\
\hline
\end{tabular}

${ }^{1}$ Control: no addition of dietary fiber and with $20 \%$ of fat; 1 : low-fat with $0.87 \%$ oat fiber plus $0.87 \%$ inulin; 2 : low-fat with $5.12 \%$ oat fiber plus $0.87 \%$ inulin; 3 : low-fat with $0.87 \%$ oat fiber plus $5.12 \%$ inulin; 4 : low-fat with $5.12 \%$ oat fiber plus $5.12 \%$ inulin; 5 : low-fat with $3 \%$ oat fiber plus $3 \%$ inulin; 6 : low-fat with $3 \%$ oat fiber plus $3 \%$ inulin; 7 : low-fat with $3 \%$ oat fiber plus 3\% inulin; 8: low-fat with 3\% oat fiber plus 3\% inulin; 9: low-fat with 3\% inulin; 10: low-fat with 6\% oat fiber plus 3\% inulin; 11: low-fat with 3\% oat fiber; 12: low-fat with $3 \%$ oat fiber plus $6 \%$ of inulin. SEM= standard error of the mean. ns: no Significant $(\mathrm{P}>0.05)$. abcdef Different lowercase letters in the same column indicate significant difference $(\mathrm{P}<0.05)$ by Tukey's test.

showed a reduction $(P<0.05)$ in $\mathrm{L}^{*}$ (Table 5) compromising the lightness value. The addition of Fructooligosaccharide and inulin at 3\% and $6 \%$ caused a reduction in the lightness value in low-fat beef burger (Bis-Souza et al., 2018). Other study reported a decreased of lightness with the increase in chia flour addition in chicken nuggets (Barros et al., 2018). The addition of the oat fiber and inulin mixed together presented an increase in lightness. This finding is in agreement with data reported by Amini Sarteshnizi et al. (2015) who observed an increase in lightness in cooked sausage with $\beta$-glucan, resistant starch and starch. Oliveira Faria et al. (2015) also reported an increase in lightness with the addition of amorphous cellulose in low-fat Bologna-type sausages.

Redness and yellowness (Table 5) of low-fat Paio increased significantly from 13.9 to 15.2 and from 13.1 to 14.5 , respectively. According to Keenan et al. (2014), the addition of inulin as a fat substitute in breakfast sausage did not show significant effect on the redness. However, the inclusion of inulin in the formulation decreased the yellowness compared to the control which had $18.7 \%$ of pork back fat. The addition of pineapple dietary fiber as a fat substitute in a beef sausage increased $b^{*}$ values, hue and Chroma, and decreased $\mathrm{a}^{*}$ values compared to the control group (Henning et al., 2016).

\section{TBARS values}

The TBARS values (Table 4 ) were not affected by oat fiber and inulin, and there was no significant difference $(P>0.05)$ between the results after 0 and 30 days of storage at room temperature. ANOVA showed $\mathrm{F}_{\text {calculated }}$ lower than $\mathrm{F}_{\text {tabulated }}$. The partial replacement of pork back fat with inulin and oat fiber in cooked Paio sausage was possible without affecting the oxidative stability of cooked Paio sausage. A similar result was observed by Ulu (2004), who evaluated cooked meatballs stored under a refrigeration temperature of $4{ }^{\circ} \mathrm{C}$ for 1 day and did not observe significant differences in the TBARS values. But after 7 days of storage at $4{ }^{\circ} \mathrm{C}$ the sample added with wheat flour showed significant higher lipid oxidation value compared to the other samples. The addition of fructooligosaccharides as a fat substitute in fermented cooked sausage (up to 9\%) did not show effect on the TBARS value throughout the storage period (60 days) (Santos et al., 2012). Similar results were reported by Ham et al. (2016) who did not observe any effect on the lipid oxidation stability.

\section{Microbiological analysis}

The microbiological analysis revealed that all the treatments were within the limits established by Brazilian Legislation (Brasil, 2001). The microbial counts were inferior to $10 \mathrm{CFU} . \mathrm{g}^{-1}$ for sulfite-reducing clostridia, inferior to $100 \mathrm{MPN} \cdot \mathrm{g}^{-1}$ for thermotolerant coliforms, inferior of $100 \mathrm{CFU} . \mathrm{g}^{-1}$ for Coagulase-Positive Staphylococci, and there was a complete absence of Salmonella sp. in $25 \mathrm{~g}$ of sample. According to these results, all the treatments of cooked Paio sausage were safe for consumption from a microbiological standpoint.

\section{Sensory Analysis}

The oat fiber and inulin did not affect the scores for color, taste and overall acceptance in cooked Paio sausage. Only the texture was affected by the oat fiber, whose scores decreased with the addition of this insoluble fiber. This is probably because the oat fiber also had an effect on the texture profile analysis (hardness, cohesiveness, springiness and chewiness), increasing all these parameters.

The model (Table 4) was built and the response surface (Figure 1f) was produced. ANOVA showed that $\mathrm{F}_{\text {calculated }}$ was higher than $\mathrm{F}_{\text {tabulated }}$. Figure if shows that with the increase in oat fiber level, the score attributed to texture is lower. This result 
agrees with Huang et al. (2011), who replaced the fat of Chinesetype sausage with oat fiber at $7 \%$ and the acceptance of the product texture was decreased. On the contrary, Bastos et al. (2014) reported that oatmeal flour as a fat substitute in low-fat beef burger increased the sensory acceptance compared to the control.

Afshari et al. (2017) reported a decrease in flavor intensity and chewiness scores with the incorporation of inulin and $\beta$-glucan but the overall acceptability scores were not significantly different from the control. Amini Sarteshnizi et al. (2015) also found correlation between texture profile analysis and sensory evaluation, the addition of $\beta$-glucan, resistant starch and starch in cooked sausage decreased the sensory score for texture and decreased the instrumental hardness.

In the study using pork skin and green banana flour gel with different levels of fat replacement in bologna-type sausage, a reduction in texture score was seen, when 80 or $100 \%$ of fat was replaced, compared to the control (Alves et al., 2016). According to Ham et al. (2016) the replacement of pork back fat (up to 50\%) with a mixture of collagen and dietary fiber did not affect texture, in small caliber fermented sausage. The use of emulsion gels prepared with chia and oat fiber as fat substitutes in fresh sausage "Longanizas" did not show any effect on the sensory properties such as colour, flavor, texture and general acceptability (Pintado et al., 2018). The partial substitution of fat by chia flour up to $5 \%$ in chicken nuggets did not affect the sensory acceptance of aroma, texture and flavor (Barros et al., 2018).

\section{Correlation}

Principal component analysis shows that the first principal component explained $40.98 \%$ of the data variation, the second principal component explained $23.24 \%$ and the third component explained $11.28 \%$, accounting for $75.5 \%$. The data presented allowed the separation of the results into three groups (Figure 2A). The treatments with lower levels of insoluble oat fiber and higher levels of inulin (1, 3, 5, 6 and 8 batches) can be explained by the sensorial parameters such as flavor, texture, color, overall acceptance, red color and elasticity. These results confirmed that the addition of inulin and oat fiber had a strong correlation with the sensorial parameters, although it did not show any significant effect on the response surface. The treatments with the highest sensory acceptance score were $1,6,5,3$ and 8 (Figure 2B), in which the oat fiber was added in a small quantity.

The addition of oat fiber in higher concentrations in cooked Paio sausage is better explained by the instrumental parameters of texture: hardness, cohesiveness, chewiness and yield. The correlation analysis showed that the sensory texture had a strong negative correlation $(P<0.05)$ with the parameters of instrumental texture (hardness and chewiness). The greater hardness and chewiness the sausages presented, the less acceptance of the sensorial texture by the consumers. The overall acceptance of low-fat Paio showed a strong positive correlation $(P<0.05)$ with flavor and texture. Thus, to increase the overall acceptance of a low-fat meat product, the flavor and texture of the final product must be maintained.
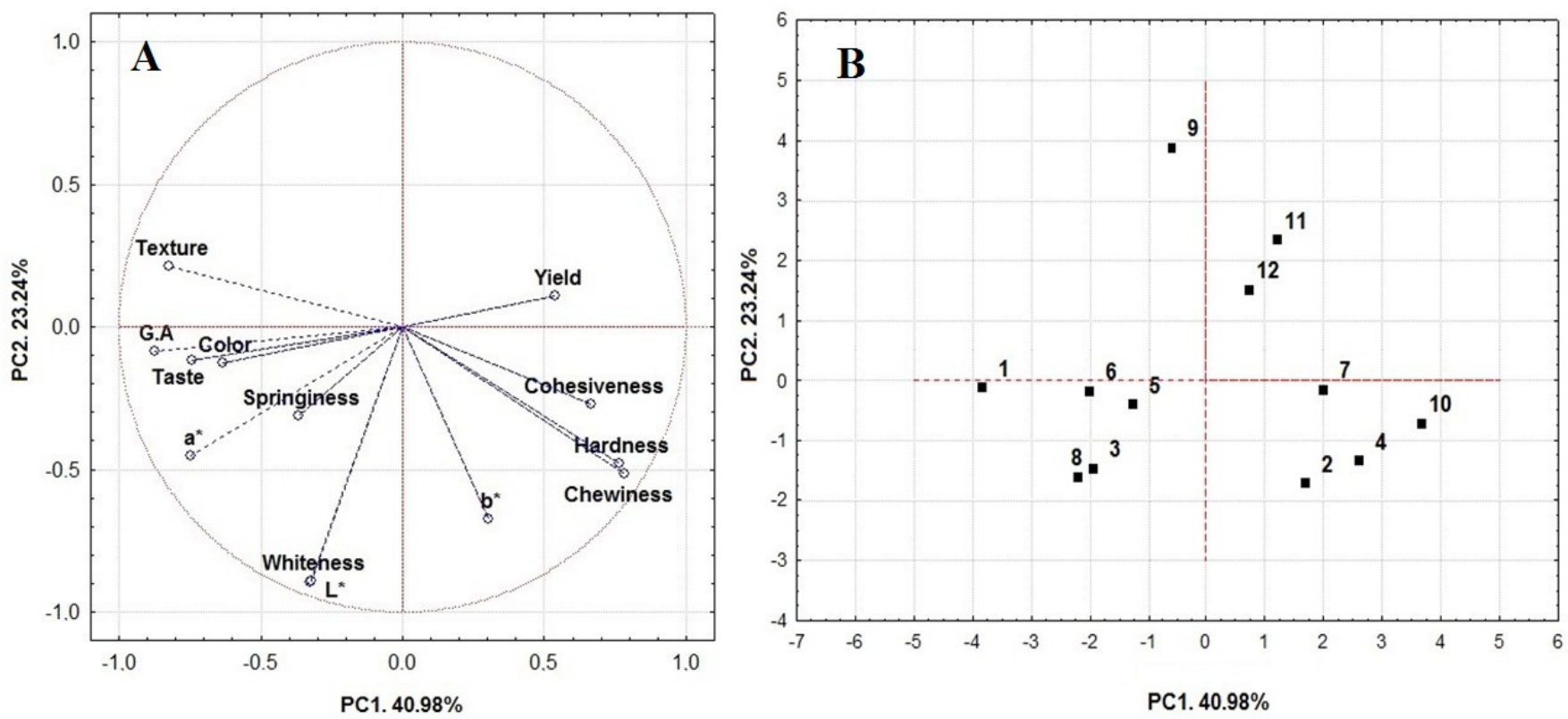

Figure 2. Principal component analysis (A- Variables projection; B- treatments projection). PC1 (40.98\%) and PC2 (23.24\%), correlating technological and sensory characteristics. 1 : low-fat with $0.87 \%$ oat fiber plus $0.87 \%$ inulin; 2 : low-fat with $5.12 \%$ oat fiber plus $0.87 \%$ inulin; 3: low-fat with $0.87 \%$ oat fiber plus $5.12 \%$ inulin; 4 : low-fat with $5.12 \%$ oat fiber plus $5.12 \%$ inulin; 5 : low-fat with $3 \%$ oat fiber plus $3 \%$ inulin; 6: low-fat with 3\% oat fiber plus 3\% inulin; 7: low-fat with 3\% oat fiber plus 3\% inulin; 8 : low-fat with 3\% oat fiber plus 3\% inulin; 9 : low-fat with $3 \%$ inulin; 10 : low-fat with $6 \%$ oat fiber plus $3 \%$ inulin; 11 : low-fat with $3 \%$ oat fiber; 12 : low-fat with $3 \%$ oat fiber plus $6 \%$ of inulin. 


\section{Conclusion}

The results of this optimization can help the meat industry to reformulate traditional meat products and make these products more attractive to consumers. The low-fat Brazilian cooked sausage with dietary fibers added maintained good yield, texture and sensorial acceptance in the concentration of $0.87 \%$ of oat fiber and up to $6 \%$ of inulin. Inulin and oat fiber can maintain the technological and sensorial parameters when added to cooked Paio sausage with up to $62 \%$ reduced fat content.

\section{Acknowledgements}

The authors would like to acknowledge the financial support from $\mathrm{CNPq}$ and FAPERP- Fundação de Apoio à Pesquisa e Extensão de São José do Rio Preto (Process nº 006/2019). José M. Lorenzo is member of the MARCARNE network, funded by CYTED (ref. 116RT0503).

\section{References}

Afshari, R., Hosseini, H., Khaksar, R., Mohammadifar, M. A., Amiri, Z., Komeili, R., \& Khaneghah, A. M. (2015). Investigation of the effects of inulin and $\beta$-glucan on the physical and sensory properties of low-fat beef burgers containing vegetable oils: Optimization of the formulation using D-optimal mixture design. Food Technology and Biotechnology, 53(4), 436-445. PMid:27904378.

Afshari, R., Hosseini, H., Mousavi Khaneghah, A., \& Khaksar, R. (2017). Physico-chemical properties of functional low-fat beef burgers: Fatty acid profile modification. Lebensmittel-Wissenschaft + Technologie, 78, 325-331. http://dx.doi.org/10.1016/j.lwt.2016.12.054.

Alves, L. A. A. D. S., Lorenzo, J. M., Gonçalves, C. A. A., Santos, B. A. D., Heck, R. T., Cichoski, A. J., \& Campagnol, P. C. B. (2016). Production of healthier bologna type sausages using pork skin and green banana flour as a fat replacers. Meat Science, 121, 73-78. http://dx.doi.org/10.1016/j.meatsci.2016.06.001. PMid:27288899.

Amini Sarteshnizi, R., Hosseini, H., Bondarianzadeh, D., Colmenero, F. J., \& khaksar, R. (2015). Optimization of prebiotic sausage formulation: Effect of using $\beta$-glucan and resistant starch by D-optimal mixture design approach. Lebensmittel-Wissenschaft + Technologie, 62(1), 704-710. http://dx.doi.org/10.1016/j.lwt.2014.05.014.

Association of Official Analytical Chemists - AOAC. (2007). Official Methods of Analysis of AOAC International. Arlington: AOAC.

Barros, J., Munekata, P. E. S., Pires, M. A., Rodrigues, I., Andaloussi, O. S., Rodrigues, C. E., \& Trindade, M. A. (2018). Omega-3- and fibre-enriched chicken nuggets by replacement of chicken skin with chia (Salvia Hispanica L.) flour. Lebensmittel-Wissenschaft + Technologie, 90, 283-289. http://dx.doi.org/10.1016/j.lwt.2017.12.041.

Bastos, S. C., Pimenta, M. E. S. G., Pimenta, C. J., Reis, T. A., Nunes, C. A., Pinheiro, A. C. M., Fabrício, L. F. F., \& Leal, R. S. (2014). Alternative fat substitutes for beef burger: technological and sensory characteristics. Journal of Food Science and Technology, 51(9), 20462053. http://dx.doi.org/10.1007/s13197-013-1233-2. PMid:25190862.

Berry, B. W. (1992). Low Fat Level Effects on Sensory, Shear, Cooking, and Chemical Properties of Ground Beef Patties. Journal of Food Science, 57(3), 537-537. http://dx.doi.org/10.1111/j.1365-2621.1992. tb08037.x.

Bis-Souza, C. V., Henck, J. M. M., \& Barretto, A. C. S. (2018). Performance of low-fat beef burger with added soluble and insoluble dietary fibers. Food Science and Technology (Campinas), 38(3), 533-529. http://dx.doi.org/10.1590/fst.09217.
Bligh, E. G., \& Dyer, W. J. (1959). A rapid method of total lipid extraction and purification. Canadian Journal of Biochemistry and Physiology, 37(8), 911-917. http://dx.doi.org/10.1139/o59-099. PMid:13671378.

Brasil. Ministério da Agricultura e Abastecimento. (2000, Março 31). Regulamento Técnico de Identidade e Qualidade de carne mecanicamente separada de frango (Instrução Normativa n 4 , de 31 de março de 2000). Diário Oficial [da] República Federativa do Brasil.

Brasil. Agência Nacional de Vigilância Sanitária. (2001, Janeiro 12). Regulamento Técnico sobre padrões microbiológicos para alimentos (Resolução RDC no 12, de 02 de janeiro de 2001). Diário Oficial [da] República Federativa do Brasil.

Brasil. Ministério da Saúde. Agência Nacional de Vigilância Sanitária. (2012, Novembro 12). Dispõe sobre o Regulamento Técnico sobre Informação Nutricional Complementar (Resolution n ${ }^{\circ} 54$, de 12 de novembro de 2012). Diário Oficial [da] República Federativa do Brasil.

Brazil. Ministry of Health. (2017). Obesity increased in $60 \%$ in ten years in Brazil. Retrieved from http://www.brasil.gov.br/saude/2017/04/ obesidade-cresce-60-em-dez-anos-no-brasil.

Carvalho, L. T., Pires, M. A., Baldin, J. C., Munekata, P. E. S., Carvalho, F. A. L., Rodrigues, I., Polizer, Y. J., de Mello, J. L. M., Lapa-Guimarães, J., \& Trindade, M. A. (2019). Partial replacement of meat and fat with hydrated wheat fiber in beef burgers decreases caloric value without reducing the feeling of satiety after consumption. Meat Science, 147, 53-59. http://dx.doi.org/10.1016/j.meatsci.2018.08.010. PMid:30196201.

Del Nobile, M. A., Conte, A., Incoronato, A. L., Panza, O., Sevi, A., \& Marino, R. (2009). New strategies for reducing the pork back-fat content in typical Italian salami. Meat Science, 81(1), 263-269. http://dx.doi.org/10.1016/j.meatsci.2008.07.026. PMid:22063993.

Domínguez, R., Munekata, P. E., Agregán, R., \& Lorenzo, J. M. (2016). Effect of commercial starter cultures on free amino acid, biogenic amine and free fatty acid contents in dry-cured foal sausage. Lebensmittel-Wissenschaft + Technologie, 71, 47-53. http://dx.doi. org/10.1016/j.lwt.2016.03.016.

Elleuch, M., Bedigian, D., Roiseux, O., Besbes, S., Blecker, C., \& Attia, H. (2011). Dietary fibre and fibre-rich by-products of food processing: Characterization, technological functionality and commercial applications: A review. Food Chemistry, 124(2), 411-421. http:// dx.doi.org/10.1016/j.foodchem.2010.06.077.

Ham, Y. K., Hwang, K. E., Kim, H. W., Song, D. H., Kim, Y. J., Choi, Y. S., \& Kim, C. J. (2016). Effects of fat replacement with a mixture of collagen and dietary fibre on small calibre fermented sausages. International Journal of Food Science \& Technology, 51(1), 96-104. http://dx.doi.org/10.1111/ijfs.12960.

Han, M., \& Bertram, H. C. (2017). Designing healthier comminuted meat products: Effect of dietary fibers on water distribution and texture of a fat-reduced meat model system. Meat Science, 133, 159-165. http://dx.doi.org/10.1016/j.meatsci.2017.07.001. PMid:28692849.

Henning, S. S. C., Tshalibe, P., \& Hoffman, L. C. (2016). Physicochemical properties of reduced-fat beef species sausage with pork back fat replaced by pineapple dietary fibres and water. LebensmittelWissenschaft + Technologie, 74, 92-98. http://dx.doi.org/10.1016/j. lwt.2016.07.007.

Huang, S. C., Tsai, Y. F., \& Chen, C. M. (2011). Effects of wheat fiber, oat fiber, and inulin on sensory and physico-chemical properties of Chinese-style sausages. Asian-Australasian Journal of Animal Sciences, 24(6), 875-880. http://dx.doi.org/10.5713/ajas.2011.10317.

Huber, E., Francio, D. L., Biasi, V., Mezzomo, N., \& Ferreira, S. R. S. (2016). Characterization of vegetable fiber and its use in chicken burger formulation. Journal of Food Science and Technology, 
53(7), 3043-3052. http://dx.doi.org/10.1007/s13197-016-2276-y. PMid:27765975.

Jiménez-Colmenero, F., Pintado, T., Cofrades, S., Ruiz-Capillas, C., \& Bastida, S. (2010). Production variations of nutritional composition of commercial meat products. Food Research International, 43(10), 2378-2384. http://dx.doi.org/10.1016/j.foodres.2010.09.009.

Keenan, D. F., Resconi, V. C., Kerry, J. P., \& Hamill, R. M. (2014). Modelling the influence of inulin as a fat substitute in comminuted meat products on their physico-chemical characteristics and eating quality using a mixture design approach. Meat Science, 96(3), 13841394. http://dx.doi.org/10.1016/j.meatsci.2013.11.025. PMid:24361558.

Kehlet, U., Pagter, M., Aaslyng, M. D., \& Raben, A. (2017). Meatballs with $3 \%$ and $6 \%$ dietary fi bre from rye bran or pea fi bre - Effects on sensory quality and subjective appetite sensations. Meat Science, 125, 66-75. PMid:27918927.

Liu, R., Wang, N., Li, Q., \& Zhang, M. (2015). Comparative studies on physicochemical properties of raw and hydrolyzed oat $\beta$-glucan and their application in low-fat meatballs. Food Hydrocolloids, 51, 424-431. http://dx.doi.org/10.1016/j.foodhyd.2015.04.027.

Meilgaard, M. C., Carr, B. T., \& Civille, G. V. (2007). Sensory Evaluation Techniques (4th ed.). CRC Press: Boca Raton. https://doi.org/10.1017/ S1431927611002686

Oliveira Faria, M., Cipriano, T. M., Cruz, A. G., Santos, B. A., Pollonio, M. A., \& Campagnol, P. C. (2015). Properties of bologna-type sausages with pork back-fat replaced with pork skin and amorphous cellulose. Meat Science, 104, 44-51. http://dx.doi.org/10.1016/j. meatsci.2015.02.002. PMid:25688689.

Petersson, K., Godard, O., Eliasson, A. C., \& Tornberg, E. (2014). The effects of cereal additives in low-fat sausages and meatballs. Part 2: Rye bran, oat bran and barley fibre. Meat Science, 96(1), 503-508. http://dx.doi.org/10.1016/j.meatsci.2013.08.019. PMid:24008058.

Pintado, T., Herrero, A. M., Jiménez-Colmenero, F., Pasqualin Cavalheiro, C., \& Ruiz-Capillas, C. (2018). Chia and oat emulsion gels as new animal fat replacers and healthy bioactive sources in fresh sausage formulation. Meat Science, 135, 6-13. https://doi.org/10.1016/j. meatsci.2017.08.004

Polizer, Y. J., Pompeu, D., Hirano, M. H., Freire, M. T. A., \& Trindade, M. A. (2015). Development and evaluation of chicken nuggets with partial replacement of meat and fat by pea fibre. Brazilian Journal of Food Technology, 18(1), 62-69. http://dx.doi.org/10.1590/19816723.4914

Santos, B. A., Campagnol, P. C. B., Pacheco, M. T. B., \& Pollonio, M. A. R. (2012). Fructooligosaccharides as a fat replacer in fermented cooked sausages. International Journal of Food Science \& Technology, 47(6), 1183-1192. http://dx.doi.org/10.1111/j.1365-2621.2012.02958.x.

Schmiele, M., Nucci Mascarenhas, M. C. C., da Silva Barretto, A. C., \& Rodrigues Pollonio, M. A. (2015). Dietary fiber as fat substitute in emulsified and cooked meat model system. Lebensmittel-Wissenschaft + Technologie, 61(1), 105-111. http://dx.doi.org/10.1016/j.lwt.2014.11.037.

Steenblock, R. L., Sebranek, J., Olson, D., \& Love, J. (2001). The effects of oat fiber on the properties of light Bologna and Fat-free Frankfurters. Journal of Food Science, 66(9), 1409-1415. http:// dx.doi.org/10.1111/j.1365-2621.2001.tb15223.x.

Tapp, W. N. 3rd, Yancey, J. W. S., \& Apple, J. K. (2011). How is the instrumental color of meat measured? Meat Science, 89(1), 1-5. http://dx.doi.org/10.1016/j.meatsci.2010.11.021. PMid:21546168.

Trevisan, Y. C., Bis, C. V., Henck, J. M., \& Barretto, A. C. S. (2016). Effect of the addition of oat fiber on the physicochemical properties of cooked frozen hamburger with reduced fat and salt. Brazilian Journal of Food Technology, 19. http://dx.doi.org/10.1590/1981-6723.7915.

Ulu, H. (2004). Effect of wheat flour, whey protein concentrate and soya protein isolate on oxidative processes and textural properties of cooked meatballs. Food Chemistry, 87(4), 523-529. http://dx.doi. org/10.1016/j.foodchem.2004.01.002.

Vyncke, W. (1970). Direct Determination of the Thiobarbituric Acid Value in Trichloracetic Acid Extracts of Fish as a Measure of Oxidative Rancidity. Fette, Seifen. Anstrichmittel, 72(12), 1084-1087. http:// dx.doi.org/10.1002/lipi.19700721218. 